\title{
Nos bares da cidade: lazer e sociabilidade em Brasília
}

\author{
Gilberto Luiz Lima Barral \\ Orientador: João Gabriel Lima Cruz Teixeira \\ Tese de Doutorado \\ Data da defesa: 28.08.2012
}

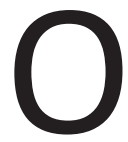

bar, em determinado espaço e tempo, aparece como lugar do advento da opinião pública, como um lócus de experiências e conhecimentos das coisas pela vivência e/ou observação, transformando-se em local de conversas e práticas de lazer políticas e culturais. Nesse sentido, esta tese de doutorado situa-se no campo de estudo das formas de sociabilidade propiciadas pelas práticas de lazer. O objetivo é observar determinada prática de lazer, particularmente no bar, com a finalidade de produzir uma sociologia do cotidiano e uma sociologia do lazer e da cultura. Investiga-se a organização e o funcionamento do bar, buscando compreender que sociabilidade se desenvolve em determinados bares de Brasília e, ainda, apresentar as redes de interdependência que envolvem e propiciam formas de ocupação e uso dos espaços da cidade. Com essa perspectiva, o objeto de estudo da tese construiu-se em torno do pensar o espaço do lazer e as formas de sociabilidade envolvidas nessas práticas em bares como configurador de uma sociabilidade específica, ora apresentada como uma sociabilidade de bar. O estudo teve, como referenciais teóricos, as ideias de autores como Erving Goffman, Georg Simmel, Johan Huizinga, Joffre Dumazedier, Norbert Elias, Michel Maffesoli, Karl Mannheim, entre outros. Para dar suporte ao argumento da tese, foi realizada uma pesquisa qualitativa, com ênfase em uma etnografia de alguns bares: observação direta, prolongada e aberta, voltada para um olhar interdisciplinar (MANNHEIM, 2001; CUNHA, 1982). Em campo, foram feitas anotações de observações, de conversas, de ideias. Ainda foram realizadas entrevistas, fotografias e produzidos registros audiovisuais que se transformaram, em parte, em vídeos. Buscando realizar uma sociologia da vida cotidiana nos bares da cidade, a pesquisa se apoiou ainda nas metodologias da sociologia da imagem e da fotografia (ACHUTTI, 1997; MARTINS, 2009). O recorte empírico proposto para se estudar a relação entre lazer e sociabilidade são alguns bares da Asa Sul de Brasília, situados nas áreas comerciais das quadras 109, 113 e 403. Na Asa Norte da cidade, as quadras comerciais 115, 216, 403, 408 e a Vila Planalto. As considerações relativas ao percurso da pesquisa e seus resultados face à construção do problema teórico e empírico proposto apontam o crescimento dos bares na cidade como espaços de lazer e sociabilidade; a projeção desses espaços nas vivências, comportamentos 
e representações dessas práticas de lazer; e as redes de interdependência que se articulam e redesenham os espaços de lazer em Brasília.

Palavras-chave: Sociologia da Cultura, Lazer, Sociabilidade, Redes de Interdependência, Interação Social, Bar, Cotidiano, Etnografia, Imagem, Comportamento, Conduta, Espaço, Cidade, Brasília. 